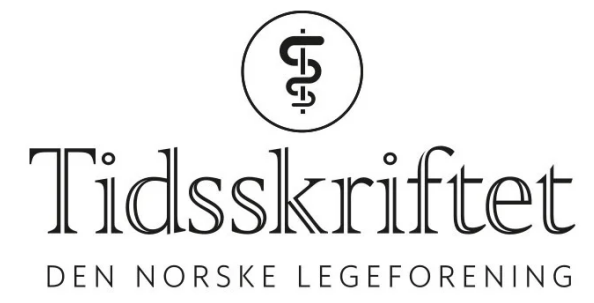

\title{
- Vi må kjønne mer forskning
}

INTERVJU

CHRISTINA SVANSTR ØM

christina@svanstrom.no

Johanne Sundby (69) arbeider for at kvinnehelse skal tas på alvor, og vil inspirere unge leger til å tro på at det er rom for mangfold i front av akademia. 


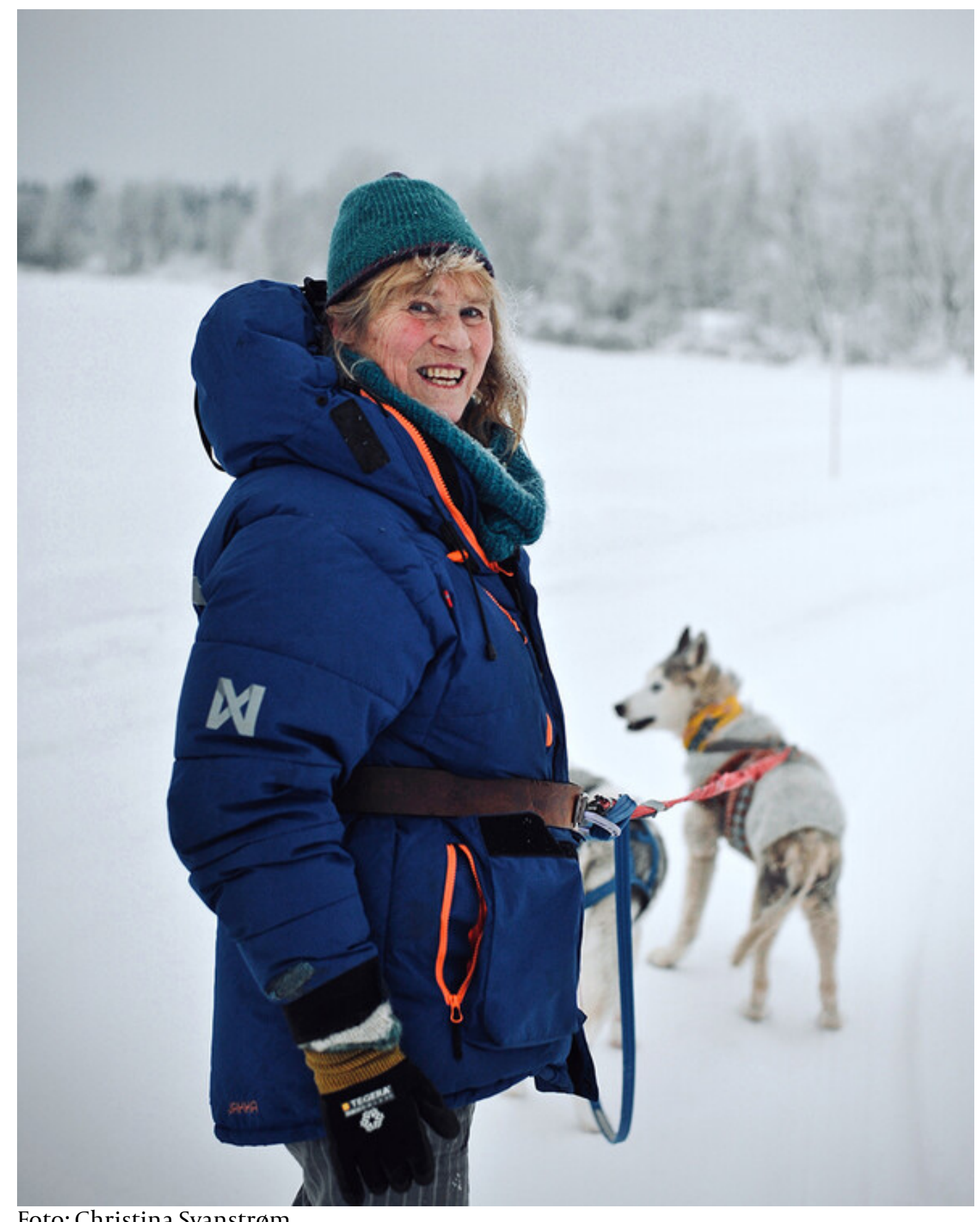

Foto: Christina Svanstrøm

Livet like utenfor Oslo var godt i mange år. For en rimelig penge kjøpte hun i sin tid et hus i Nordmarka. Et sted som muliggjorde jobb på Universitetet i Oslo, forskningsprosjekter i Afrika, omsorg for aldrende foreldre og aktiv hundekjøring. Togstoppet «Snippen» på Gjøvikbanen var i mange år kun brukt fast av henne og et knippe andre mennesker. Men pandemien skulle drive Johanne og bikkjene vekk fra Oslomarka og ut på landet.

- Med korona ble det helt vanvittig mye folk. Det lå nesten som "gayparader» med fargerike hengekøyer langs veien, og små bål hvor turfolk fyrte minigriller. Villmarka jeg bodde i grenseland til ble borte. Det ble umulig å drive med hund.

Huset ble solgt sommeren 2020. Straks etter åpnet det seg en ny mulighet nordøst for Mjøsa i Ringsaker kommune. Et rødt, lite og lunt hus i enden av en vei som kilometer for kilometer snirkler seg stadig smalere vekk fra Brumunddal sentrum.

- Nå er jeg her. Det er fint, få folk, og plass til å drive hundekjøring. Jeg har alltid hatt hjelp boende hos meg eller i nærheten, som gjør at hundeholdet lar seg kombinere med arbeidslivet. Slik er det også nå. 
For folk i Brumunddal er det nok lett å avskrive den voksne tilflytteren som én av flere byfolk på søken etter lykken i landlige omgivelser. Når hun tar med seg spannet ut i skogen, eller rusler med noen av bikkjene langs vegen, gjemmer det seg godt levd liv under ei værhard dunjakke.

- Her ute har jeg ingen rolle. Jeg er ikke noens lege, jeg er ikke kjent for noen. Det gjør ikke noe. Det er ikke så viktig for meg at enkeltmomenter i mitt liv blåses ut av proporsjoner, og skal gi et inntrykk av «hvem jeg er». Alt er for komplisert til det. Men jeg vil vise at det finnes mange alternativer i legelivet, og at valg som mine også er mulige.

\section{Eventyrlysten}

En fri men trygg barndom, oppdratt av en barnepsykiater og en sosialmedisiner. Eldst av fire søsken. Et hjem med rom for diskusjoner og egne meninger. Hun har alltid vært politisk engasjert, og «lusket rundt i synse-og-mene-menigheten» på venstresida. Skribent i Klassekampen, Bistandsaktuelt og Uniforum. Forfatter av fagbøker, hundebok og pennefører i blader om sin store lidenskap: hundekjøring.

\section{Johanne Sundby}

Født 1951

Cand.med., Universitetet i Oslo 1979

Spesialist i fødselshjelp og gynekologi 1990

Ph.d.-stipendiat ved Folkehelseinstituttet og rådgiver i Helsetilsynet 1988-1994

Dr.med. i samfunnsmedisin 1994

Postdoktor i internasjonal reproduktiv helse, Universitetet i Oslo 1994-96

Leder, NOU Nor 13, 1999, om kvinners helse i Norge

Professor i samfunnsmedisin og global helse, Universitetet i Oslo

Sittet 6 år i styret i WHOs forskningsprogram HRP

Ledet program i Forskningsrådet, Utviklingsveier i Sør

- I tillegg er det vitenskapen. En må skrive artikler på universitetet helt til professoratet. Men det har ikke vært så viktig for meg å være superakademiker. Jeg er mer opptatt av kapasitetsbygging og anvendbarhet. Jeg vil få de yngre og de fra Sør til å tro at de kan bli forskere og at deres erfaringer er relevante å forske på.

Selv om både studier og tidlig karriere ble etablert i Norge, har storparten av Sundbys profesjonelle liv hatt blikket rettet utad. Mot utviklingsprosjekter og kapasitetsbygging nedenfra-og-opp.

"Jeg vil vise at det finnes mange alternativer i legelivet, og at valg som mine også er mulige»

- Hvordan begynte interessen for global helse?

- Flere årsaker, men eventyrlysten var noe av det. I tenårene dro jeg på utveksling til USA, havnet i en sørstat, og ble der veldig opptatt av forholdet mellom svarte, hvite og meksikanere. I 1975, da jeg var student, tok faren min meg med på en reise til Kina med tog. En faglig innrettet reise for leger som var interessert i samfunnsspørsmål. Det var et Kina langt fra hva det er nå, den gang alle gikk i blå skjorter, var fattige og veldig kommunistiske. 
Det andre som ledet Sundbys forskning ut av Norge var faginteressen hennes. Etter å ha blitt gynekolog, og forsket på fertilitet, fruktbarhet og barnløshet i Norge, fikk hun gjennom Forskningsrådet midler til å se på barnløshet i Afrika. Det ene ledet til det andre, og på go-tallet tok det form av et transnasjonalt nettverk hun skulle være del av i mange år framover. Barnløshet og mødrehelse kom på dagsordenen i store deler av verden.

Siste steg ut av klinikken ble da Sundby fikk oppdraget med å forberede den norske posisjonen i befolkningskonferansen i Kairo i 1994.

- Det var en banebrytende konferanse, der rettigheter i befolkninger og fruktbarhet stod sentralt. Jeg var med i den norske delegasjonen og fikk delta i skikkelig toppolitikk på mitt fagfelt. Da jeg etterpå fikk postdoktoren i Oslo, ble det starten på arbeidet med global helse jeg fortsatte med til nå.

\section{Barnløshet}

Da Sundby reiste til Afrika for å snakke om barnløshet, ble mange overrasket av hva hun fant.

- Det var helt klart at det var et tema som var relevant, men ikke tatt fatt i. Jeg fant like mange ufrivillig barnløse der som i Norge. 


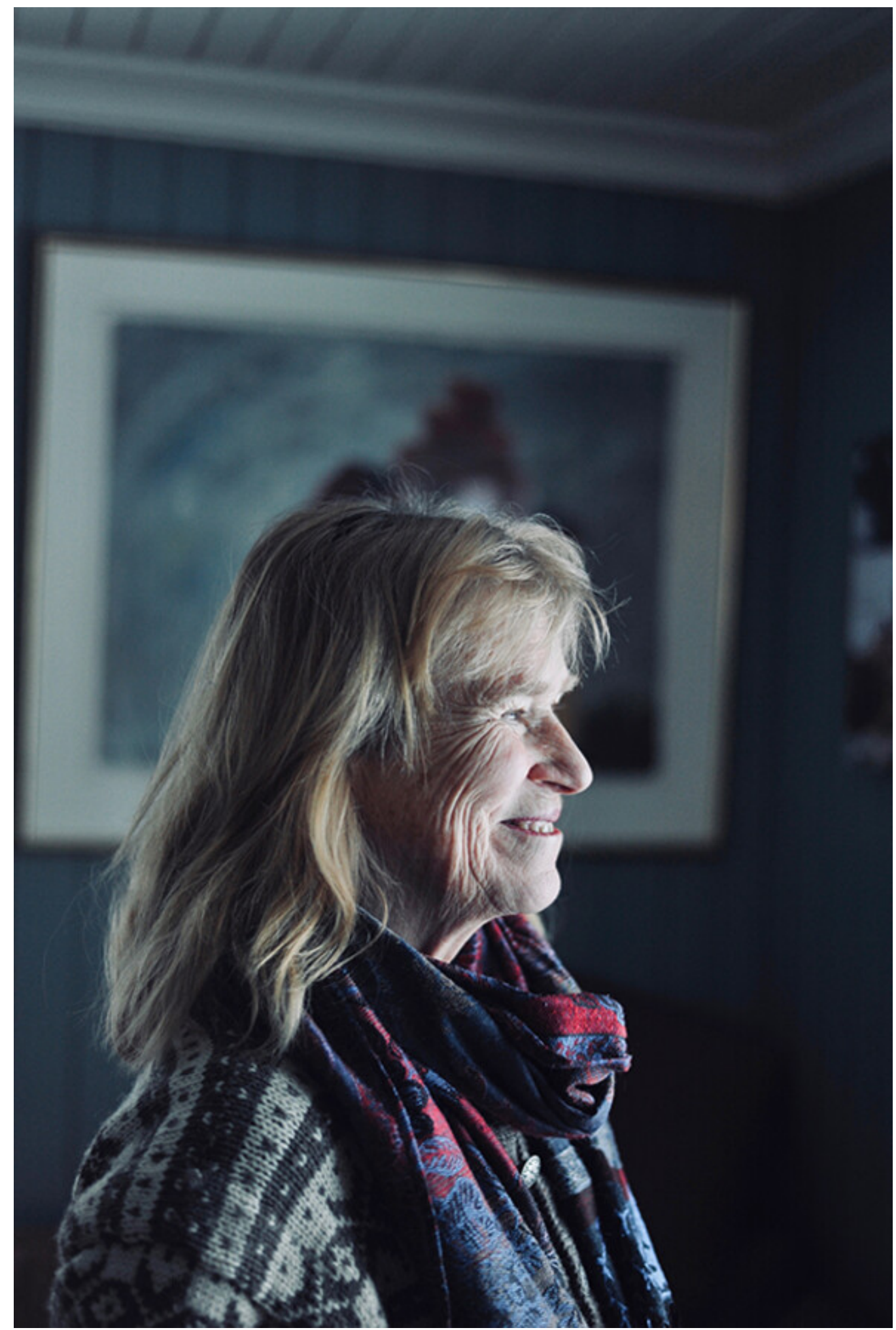

Foto: Christina Svanstrøm

- Hvordan var det å ta noe du personlig har opplevd inn i forskning?

- Vanskelig. Til å begynne med sa de at jeg måtte holde min egen erfaring skjult. Jeg kunne si at jeg var gynekolog, men ikke at jeg hadde opplevd barnløshet. Men det butta veldig imot hos meg. For mange av forskningsspørsmålene var spørsmål jeg hadde stilt fordi jeg hadde lurt på det, og ikke hadde noen svar i empirien. I medisinsk antropologi fant jeg senere en legitimitet for det jeg hadde gjort, som ikke fantes i den gamle epidemiologien. Det ga meg en vei å gå med forskningsspørsmål jeg ikke ville hatt om jeg ikke hadde opplevd det selv. Jeg vil ikke kalle det bias, men en døråpner.

- Er det noe som har endret seg til det bedre i tiden du har jobbet med global kvinnehelse? 
- Tja. Det går veldig i bølger. Det var en periode rundt millenniumsmålene der det var veldig fokus på mødrehelse og dødelighet. Med bærekraftsmålene falt det litt vekk igjen. Jeg holder ved at reproduktiv helse er viktig, andre mener det er umoderne.

- Hvilke konsekvenser får pandemien for global kvinnehelse?

- Det har virkelig vært et tilbakeslag i forhold til tjenesteyting.

\section{Forskjellen på menn og kvinner}

Siden fikk hun oppdraget med å lede en av Norges offentlige utredninger (NOU) om kvinnehelse i Norge, som ble levert i 1999.

-Vi så på biologi, kvinnehelse, og kvinner i samfunnet. I medisinen har man oversett kjønn som variabel. Men for menn og kvinner er veien ulik inn i sykdom eller uførhet, og risikofaktorene og taklingen forskjellig. Vi mister informasjon hvis vi ikke ser på det med et kjønnet blikk.

- Hvordan har det blitt tatt imot?

- Det har blitt tatt godt imot av mange unge kvinnelige leger og folk som jobber i helsevesenet som skjønner det intuitivt. Noen påstår at det ikke er forskjell på kvinner og menn, og at jeg som kvinne har akkurat like muligheter som menn. At de tingene som hefter ved kvinner ikke finnes.

- Vi skal være likestilt ellers, men altså forskjellige i medisin. Jeg ser for meg at dette kan være vanskelig å formidle?

«I idretten er vi kjempeflinke til å kjønne ting. Ingen tror at menn og kvinner kan konkurrere på like vilkår. Sånn er det bare. I medisinen gjør vi mange feil fordi vi ikke ser at kvinner og menn ofte skal behandles ulikt»

- Noen synes at det med kjønn blir kjedelig eller uinteressant. Noen føler seg truffet, eller mener vi legger skylden på menn for at kvinnen er underordnet. Men det handler om det strukturelle og at historisk sett har det vært en større forskjell. I idretten er vi kjempeflinke til å kjønne ting. Ingen tror at menn og kvinner kan konkurrere på like vilkår. Sånn er det bare. I medisinen gjør vi mange feil fordi vi ikke ser at kvinner og menn ofte skal behandles ulikt. 


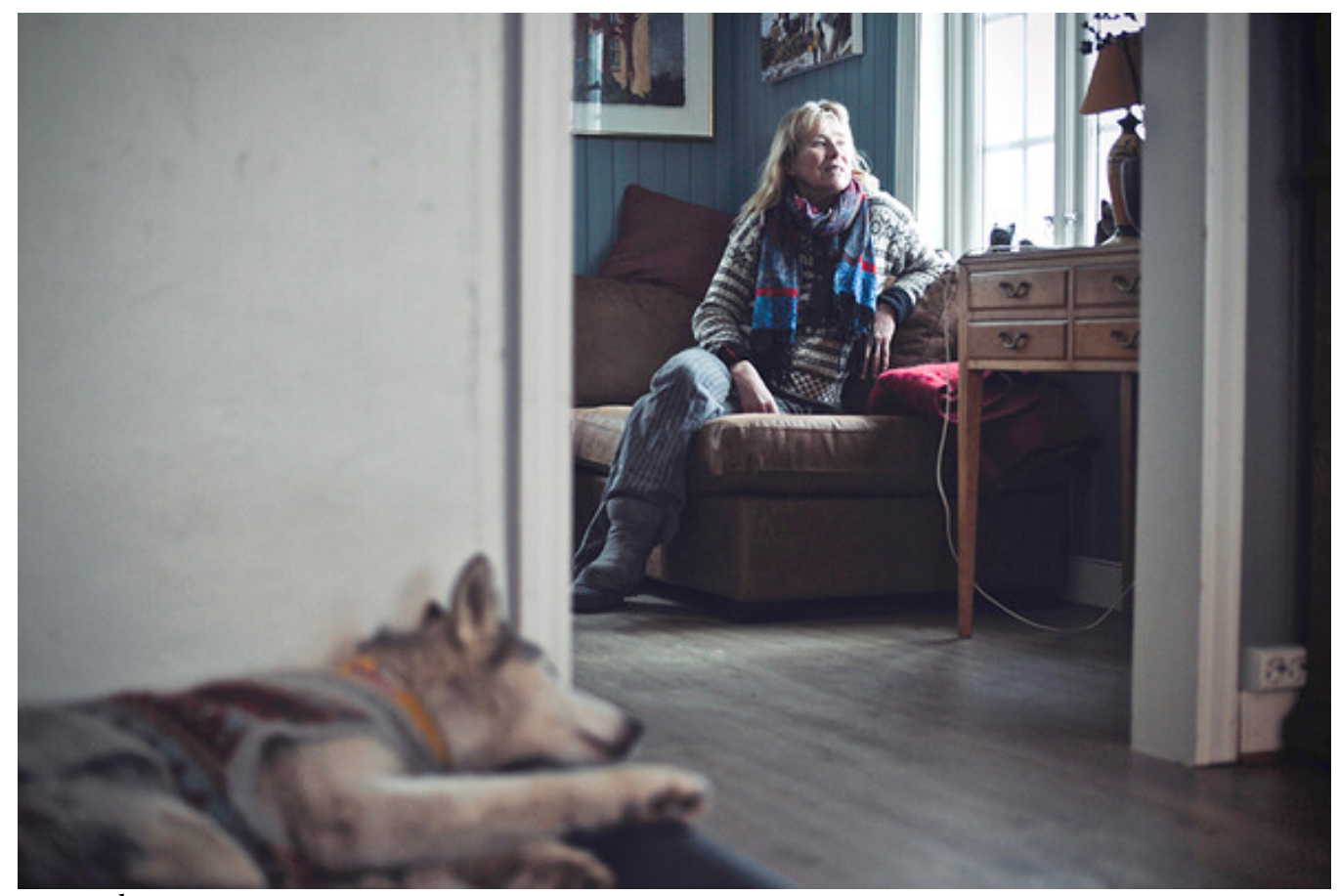

Foto: Christina Svanstrøm

- Klarer du få dem som ikke ønsker å høre til å lytte?

- Jeg gjør vel ikke det. Nå er det bestemt at de må lage en ny NOU om kvinnehelse, 25 år etter den første. Den hadde en viss effekt, men ikke stor nok. Jeg har vært med å gi innspill i starten, men vi som er gamle i tralten skal overlate dette til de yngre som eier samfunnet nå. Det er bra at de legger premissene for hvordan det blir videre.

- Når ble det en greie at du var for gammel for ting?

- Det er ikke så tydelig. Men jeg merker for eksempel i noen diskusjonsgrupper at vi krasjer i synet på seksualitet. Jeg mener at kvinner kanskje fremdeles må passe litt på seg selv. Hvis det blir for liberalt, går det til syvende og sist utover kvinnen. Enkelte unge kvinner vil ikke være ved at det er noen maktføringer i seksualiteten.

Sundby sier hun er for seksuell frihet. Men at hun som praktiker har opplevd skyggesiden av en del eksperimentering.

- Jeg har sett unge jenter som har trådt inn i ting som ikke har vært bra for dem. Da mener jeg ikke å si at en selv har ansvar for å ikke bli voldtatt, men det er noe med å tørre å si nei til ting for å kunne si ja til det du faktisk vil. Der tror jeg en del av den yngre generasjonen ser på oss som gamle kjerringer.

\section{Å bygge kapasitet}

De stedene i verden hvor Sundby har arbeidet, har det vært en grunnforutsetning å bygge kapasitet. Ikke ta over, men lære videre, godt støttet av litt midler, veiledning og heiarop.

- Jeg har tenkt at jeg kan hjelpe folk til å finne ut hvordan de skal peke på hvor skoen trykker. Hvis det kommer fra dem selv er det mye bedre enn om det kommer fra meg. Jeg liker å se at folk når potensialet sitt fullt ut.

Mastergraden i Internasjonal samfunnshelse på UiO står som noe av det hun er svært stolt over å skape. Egentlig bød fjoråret på smaken av akademisk pensjonstilværelse, men det har ikke vært lett å gi slipp.

- Jeg synes ikke digital undervisning har vært så morsomt, men har holdt på et år til likevel. Og jeg har folk som kan passe på bikkjene her mens jeg er borte. 
Selv om hun noen uker reiser til Oslo for å være på kontoret eller med sønnen Sjur og barnebarna, er livet nå i Ringsaker. Lidenskapen for hunder har i mange år vært viktig mental hygiene for kvinnehelseforskeren.

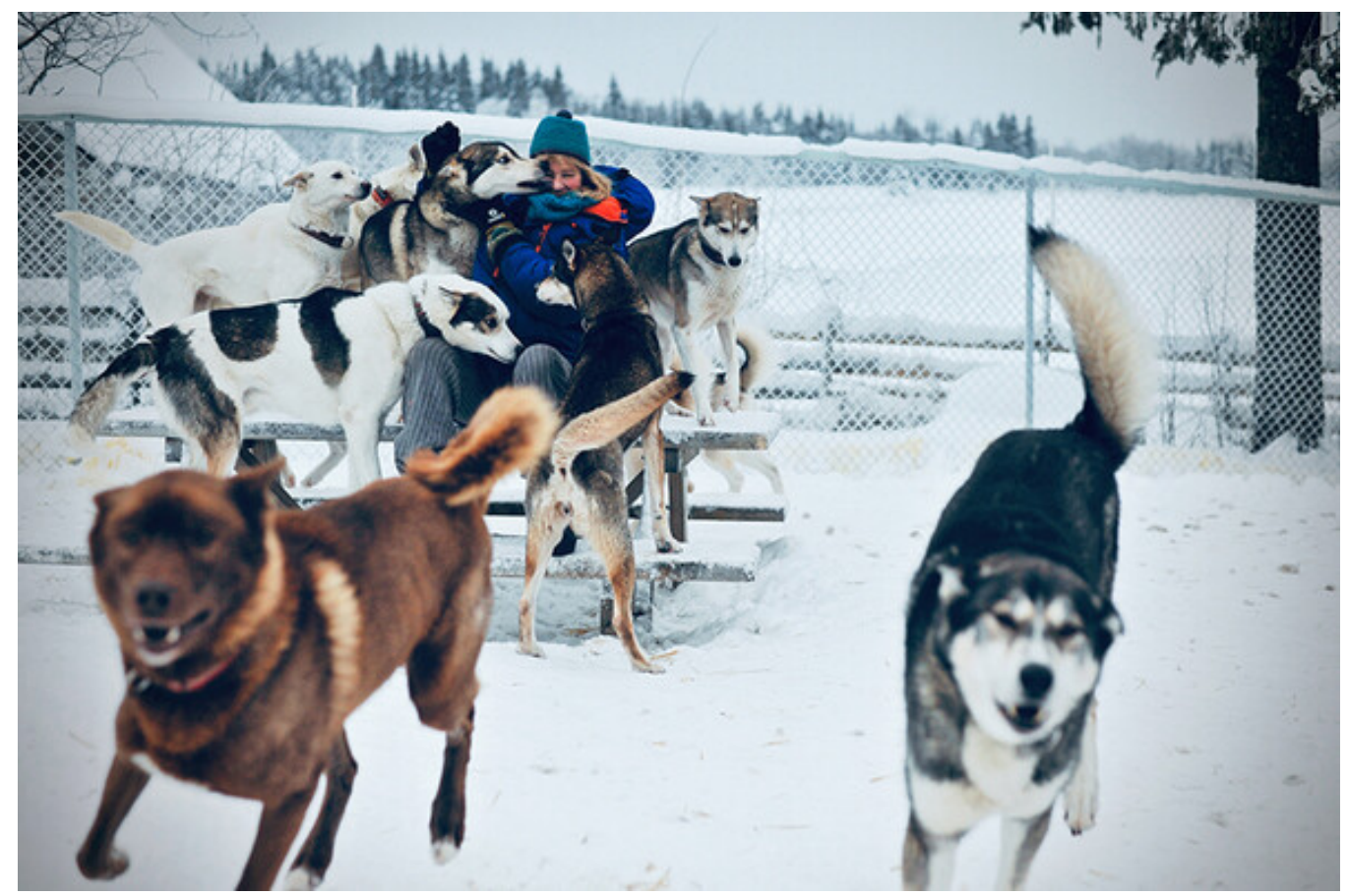

Foto: Christina Svanstrøm

- Hundekjøringa har gitt meg adspredelse, glede og meditasjon. Jeg egner meg ikke for yoga, har lopper i blodet, og trenger action for ikke å bli deprimert. Når jeg står på hundesleden er det noen ganger nesten som dop, det er et kick som gjør at ting faller litt på plass. Jeg er alltid litt redd, og samtidig glad dette er hva jeg holder på med.

\section{«Det handler ikke så mye om meg, men heller hva jeg kan gjøre med verden»}

Alt begynte med en valp hun fikk av datteren til den kjente pelsjegeren Helge Ingstad.

- Vi jobbet sammen på universitetet. Hun hadde huskyer fra sin far og ga meg en liten sorthvit valp på hjemlån. Så fikk jeg enda en. Etter hvert kjørte jeg med hundene hennes, og til slutt kjøpte jeg alle og flyttet slik til at jeg kunne ha dem.

Innhengninga til hundegården strekker seg rundt store deler av det lille røde huset. Rullegardinen på badet er falt ned fra festet. Det gjelder å ikke være sjenert. Rett ved siden av toalettet står skuelystne hunder og gnir snuten mot glasset på terrassedøra. De to heldige som får lov til å komme inn fra det hustrige været utenfor er den eldste og yngste. Gamlingen på 15 år har ikke pels nok og bærer derfor en spesialstrikka Villmarksgenser over nakke og skuldre.

- Han er helt på overtid, med en endokrin forstyrrelse, en svulst i ballen, og mangel på både hår, sædceller og negler. Men han er veldig snill. Og fortsatt veldig glad i mat og turer.

Hun har alltid likt landsbygda og villmarka. Etter et aktivt liv med arbeid og eventyr, har hun sammen med sine unge og gamle firbente venner funnet nye muligheter $\mathrm{i}$ Brumunddal.

- Jeg var redd for å bli ensom, men selv i koronatiden har det vært fint å bo her. Mange på min alder blir mer satt med årene enn hva jeg ønsker å bli. Det er det siste jeg kunne tenkt meg.

- Å bli gammel, tenker du? 
- Jeg vet ikke, ja. Jeg er ikke redd for å bli gammel, men huttetu å komme på institusjon og bli pleiet av noen som ikke aner hvem du er. Hva er det å bli gammel? Hvordan respekterer og forholder vi oss til det? Den tid den sorg. Men det er et stort samfunnsspørsmål.

- Tenker du selv at du har hatt et innholdsrikt liv?

- Du kan så si. Jeg hadde sett for meg noe litt som moren og faren min hadde. En mann som gjorde som meg, få noen unger, gjøre karriere som lege. Jeg fant to slike menn, men det varte ikke. Når det ikke ble som planlagt måtte jeg gjøre mange andre valg. Det har gjort meg modig. Jeg passer ikke til å være som mange andre, jeg passer bedre til å være opposisjonell. Det handler ikke så mye om meg, men heller hva jeg kan gjøre med verden.

Publisert: 29. april 2021. Tidsskr Nor Legeforen. DOI: 10.4045/tidsskr.21.0138

(C) Tidsskrift for Den norske legeforening 2023. Lastet ned fra tidsskriftet.no 26. april 2023. 